\title{
POTASSIUM STATUS AND ITS EXTRACTION FREE ENERGY IN SOME NEWLY RECLAIMED SOILS AT UPPER EGYPT
}

\author{
Magdy H. Khider \\ Soils, Water and Environ. Institute, Agric. Res. Center, Giza, Egypt
}

\begin{abstract}
:
Eight surface soil samples $(0-30 \mathrm{~cm})$ were selected from some newly reclaimed soils at Kom Ombo and Halaib \& Shalateen areas, Upper Egypt, Egypt to identify K status and free energy of extracted $\mathrm{K}$ amounts. The obtained data reveal that the amounts of soluble and exchangeable $\mathrm{K}$ ranged between $0.006-0.286$ and $0.12-1.65 \mathrm{~m}$ $\mathrm{mol}_{\mathrm{c}} / 100 \mathrm{~g}$ soil, respectively. Also, the corresponding K amounts take place a similar parallel trend to each of soil salinity level and the content of clay fraction, respectively.

The $\mathrm{CaCl}_{2}$ extractable $\mathrm{K}$ contents from the soil samples under consideration ranged between 0.39-0.13 and 0.05-0.02 me/100 g soil at the first and last extractions, respectively. These obtained data show a greater depletion between the fine and coarse textured soils. In addition, free energy values $(\Delta \mathrm{F})$ of $\mathrm{K}$ extractions were calculated, and the obtained results indicate that the released $\mathrm{K}$ amounts from the studied soils are insufficient to cover $\mathrm{K}$ requirements for grown plants, and in turn these soils are in need to be fertilized with $\mathrm{K}$, particularly upon the prevailing extensive cropping patterns.
\end{abstract}

Key words: K status, free energy of extracted K, soils of Upper Egypt.

\section{INTRODUCTION:}

Modern agricultural practices largely rely on supplying power capacity of nutrients to achieve high yield. It is widely recognized that soil application of mineral fertilizers, especially those are of easily soluble in soil solution such as potassium, can result in minimizing the possible loss of $\mathrm{K}$ by leaching through the relatively coarse textured soils. Cooper et al. (1987) reported that easily soluble nutrient responses are closely related to applied amounts of water and rainfall and tend to decrease with decreasing soil retained of available moisture content.

$\mathrm{K}$ requirements of many economic crops are reflected on both yield and quality parameters. Potassium is clearly the most abundant element in plant tissues, where it plays a major role in various physiological and biochemical processes, including photosynthesis, water and nutrients transformation, enzyme synthesis and rate of plant respiration. In this respect, Mohamedin et al. (2003) and Abdel Mawly and Sharkawy (2004) showed that crop yield and K-use efficiency were significantly increased as a result of increasing available soil potassium levels as compared to the control treatment.

Kom Ombo and Halaib \& Shalateen areas are mostly found as virgin soils, so a spot light should be made on their supplying power capacities for different essential nutrients for plants. $\mathrm{K}$ represents one of the essential macronutrients as reported before, thus some previous studies were carried out on the characteristics of the more easily replaceable potassium and other nutrients, and their relationship to plant uptake. Woodruff $(1955$ a \& b)

Fayoum J. Agric. Res. \& Dev., Vol. 20, No. 2, July, 2006 
introduced the $\mathrm{K}$ quantity as a measure of the free energy of exchange of $\mathrm{K}$ by $\mathrm{Ca}$ in the soil, as follows:

$$
\Delta \mathrm{F}=\mathrm{RT} \operatorname{Ln}\left\{\mathrm{AK} /[\mathrm{A}(\mathrm{Ca}+\mathrm{Mg})]^{1 / 2}\right\}
$$

Where: $\mathrm{R}$ is gas constant, $\mathrm{T}$ is absolute temperature and $\mathrm{A}=$ refers to the ion activities in solution.

The $\Delta \mathrm{F}$ is proportional to the difference in the chemical potential of $\mathrm{K}$ and $\mathrm{Ca}$ in the solid phase and it is considered to be a measurement of the instantaneous availability of potassium. Energy exchange values can be categorized into:

a) -3500 to -4000 calories are associated with $\mathrm{K}$ deficiency for plant.

b) -2500 to -3000 calories represent suitable balance between $\mathrm{K}$ and $\mathrm{Ca}$.

c) -2000 calories or more are associated with excessive amounts of $\mathrm{K}$ in solution to amounts of $\mathrm{Ca}$ that are present.

A massive goal of the Egyptian Government is to increase the agricultural areas and their productivities. That needs more emphases, i.e., good irrigation water and fertilization management practices, which are considered successful tools to achieve high production for the grown crops. Thus, the current work aimed at evaluating $\mathrm{K}$ supplying power capacity of some promising soils for agricultural utilization at Upper Egypt. Also, K status and its extraction free energy as affected by soil sediment natures will be a matter of course in this investigation.

\section{MATERIALS AND METHODS:}

Eight surface soil samples $(0-30 \mathrm{~cm})$ were selected from some newly reclaimed soils at Kom Ombo and Halaib \& Shalateen areas, Upper Egypt. Some physical and chemical properties of the studied soil samples were determined as follows:

a. Particle size distribution was determined using the International Pipette Method (Kilmer and Alexander, 1949).

b. Soil $\mathrm{pH}$ in soil paste, salinity as expressed in ECe $(\mathrm{dS} / \mathrm{m})$ and soluble ions (cations and anions in $\mathrm{m} \mathrm{mol}_{\mathrm{c}} \mathrm{L}^{-1}$ ) were determined in soil paste extract according to Jackson (1973).

c. Water soluble $\mathrm{K}$ by calculation as $\mathrm{m} \mathrm{mol}_{\mathrm{c}} / 100 \mathrm{~g}$ soil using the data obtained from soil paste extract analysis.

d. Cation exchange capacity and exchangeable cations were determined using the methods outlined by Richards (1954).

e. Exchangeable $\mathrm{K}$ was extracted by $1 \mathrm{~N} \mathrm{NH}_{4}-\mathrm{OAc}$, and it was Flame Photometrically determined (Jackson, 1973).

f. The successive extractions were carried out using $0.01 \mathrm{~N} \mathrm{CaCl}_{2}($ Hagin and Feigenbaum, 1962), where a portion of $5 \mathrm{~g}$ of each soil were treated with $50 \mathrm{ml} 0.01 \mathrm{~N} \mathrm{CaCl}_{2}$ solution, shaken for 15 minutes and then centrifuged. The supernatants were used for determining $\mathrm{Ca}, \mathrm{Mg}$ and $\mathrm{K}$. This process was repeated several times until the $\mathrm{K}$ concentration in the last three successive extracts reached a constant value

\section{RESULTS AND DISCUSSION:}

\section{A general view on the studied soil samples:}

It is noteworthy that the selected soil sites represent scattered areas that are mainly encompassing the Eocence limestone (Kom Ombo area) and Nubian sandstone (Halaib \& Shalateen) as parent materials. Also, their soils are developed under climatic conditions of long hot rainless summer and

Fayoum J. Agric. Res. \& Dev., Vol. 20, No. 2, July, 2006 
short mild winter, with scare amounts of rainfall. Data present in Tables $(1,2$ and 3) show that the soils under investigation are of different textural grades (i.e., loamy sand, sandy loam, sandy clay loam, clay loam and clay), and various soil salinity levels (i.e., non-saline, slightly saline, saline and strongly saline). However, they were all non-sodic soils, since their ESP values were $<15)$. Their CEC values ranged between 4.90 and $35.52 \mathrm{c} \mathrm{mol}_{\mathrm{c}} \mathrm{kg}^{-1}$ soil according to the textural grades.

Table (1): Particle size distribution and texture classes of the studied soil samples.

\begin{tabular}{|c|c|c|c|c|c|c|}
\hline \multirow{2}{*}{ Location } & Soil sample & \multicolumn{4}{|c|}{ Particle size distribution $\%$} & \multirow{2}{*}{ Texture class } \\
\cline { 2 - 7 } & No. & C. sand & F. sand & Silt & Clay & \\
\hline \multirow{3}{*}{$\begin{array}{c}\text { Kom } \\
\text { Ombo }\end{array}$} & 1 & 9.85 & 35.62 & 27.63 & 26.90 & Sandy clay loam \\
\cline { 2 - 7 } & 2 & 39.47 & 25.72 & 16.93 & 17.88 & Sandy loam \\
\cline { 2 - 7 } & 3 & 3.91 & 11.06 & 42.85 & 42.18 & Clay \\
\hline \multirow{3}{*}{$\begin{array}{c}\text { Halaib \& } \\
\text { Shalateen }\end{array}$} & 4 & 15.57 & 17.66 & 27.25 & 39.52 & Clay loam \\
\cline { 2 - 7 } & 5 & 24.91 & 47.08 & 10.03 & 17.98 & Sandy loam \\
\cline { 2 - 7 } & 6 & 26.87 & 41.13 & 9.55 & 22.45 & Sandy clay loam \\
\cline { 2 - 7 } & 8 & 69.54 & 11.30 & 6.78 & 12.38 & Loamy sand \\
\hline
\end{tabular}

Table (2): Chemical analysis of soil paste extract for the studied soil samples.

\begin{tabular}{|c|c|c|c|c|c|c|c|c|c|c|c|}
\hline \multirow{2}{*}{ Location } & \multirow{2}{*}{$\begin{array}{l}\text { Soil } \\
\text { No. }\end{array}$} & \multirow{2}{*}{$\begin{array}{c}\text { Soil } \\
\mathrm{pH}\end{array}$} & \multirow{2}{*}{$\begin{array}{c}\mathrm{ECe} \\
(\mathrm{dS} / \mathrm{m})\end{array}$} & \multicolumn{4}{|c|}{ Soluble anions $\left(\mathrm{m} \mathrm{mol}_{\mathrm{c}} \mathrm{L}^{-1}\right)$} & \multicolumn{4}{|c|}{ Soluble cations $\left(\mathrm{m} \mathrm{mol}_{\mathrm{c}} \mathrm{L}^{-1}\right)$} \\
\hline & & & & $\mathrm{CO}_{3}{ }^{2-}$ & $\mathrm{HCO}_{3}^{-}$ & $\mathrm{Cl}^{-}$ & $\mathrm{SO}_{4}{ }^{2-}$ & $\mathrm{Ca}^{2+}$ & $\mathrm{Mg}^{2+}$ & $\mathrm{Na}^{+}$ & $\mathrm{K}^{+}$ \\
\hline \multirow{4}{*}{$\begin{array}{l}\text { Kom } \\
\text { Ombo }\end{array}$} & 1 & 7.40 & 1.73 & 0.00 & 2.70 & 10.0 & 5.45 & 6.78 & 2.25 & 8.80 & 0.32 \\
\hline & 2 & 7.50 & 2.34 & 0.00 & 1.60 & 5.0 & 18.28 & 8.89 & 2.73 & 13.00 & 0.26 \\
\hline & 3 & 7.50 & 3.16 & 0.00 & & 16.0 & & 10.50 & & & 0.78 \\
\hline & 4 & 7.80 & 2.37 & 0.00 & 2.10 & 6.0 & 16.92 & 9.1 & 6.09 & 9.2 & 0.62 \\
\hline \multirow{4}{*}{$\begin{array}{l}\text { Halaib \& } \\
\text { Shalateen }\end{array}$} & 5 & 7.40 & 12.34 & 0.00 & 2.00 & 99.0 & 22.00 & 20.00 & 15.40 & 86.5 & 1.10 \\
\hline & 6 & 7.50 & 3.50 & 0.00 & 2.50 & 21.0 & 12.90 & 8.00 & 6.50 & 21.60 & 0.30 \\
\hline & 7 & 7.40 & 7.60 & 0.00 & 2.50 & 56.5 & 18.93 & 14.50 & 12.30 & 50.70 & 0.43 \\
\hline & 8 & 7.10 & 75.00 & 0.00 & 2.00 & 660.0 & 141.0 & 110.0 & 60.00 & 620.0 & 13.00 \\
\hline
\end{tabular}

Table (3): Cation exchange capacity, exchangeable cations, ESP and soluble K for the studied soil samples.

\begin{tabular}{|c|c|c|c|c|c|c|c|c|}
\hline \multirow[t]{2}{*}{ Location } & \multirow{2}{*}{$\begin{array}{l}\text { Soil } \\
\text { No. }\end{array}$} & \multirow{2}{*}{$\begin{array}{c}\text { CEC } \\
\left(\mathrm{c} \mathrm{mol}_{\mathrm{c}} \mathrm{kg}^{-1}\right)\end{array}$} & \multicolumn{4}{|c|}{$\begin{array}{l}\text { Exchangeable cations } \\
(\mathrm{m} \mathrm{mol} / 100 \mathrm{~g} \text { soil })\end{array}$} & \multirow[t]{2}{*}{ ESP } & \multirow{2}{*}{$\begin{array}{c}\text { Soluble K } \\
(\mathrm{m} \mathrm{mol} / 100 \mathrm{~g} \\
\text { soil }) \\
\end{array}$} \\
\hline & & & $\mathrm{Ca}$ & $\mathrm{Mg}$ & $\mathrm{Na}$ & $\mathrm{K}$ & & \\
\hline \multirow{4}{*}{$\begin{array}{l}\text { Kom } \\
\text { Ombo }\end{array}$} & 1 & 21.92 & 11.40 & 7.80 & 1.20 & 0.56 & 5.47 & 0.013 \\
\hline & 2 & 14.45 & 9.11 & 2.50 & 0.80 & 0.40 & 5.54 & 0.006 \\
\hline & 3 & 35.52 & 18.50 & 11.75 & 2.30 & 1.65 & 6.48 & 0.042 \\
\hline & 4 & 31.60 & 17.10 & 9.40 & 2.03 & 1.45 & 3.35 & 0.030 \\
\hline \multirow{4}{*}{$\begin{array}{l}\text { Halaib \& } \\
\text { Shalateen }\end{array}$} & 5 & 12.60 & 6.15 & 4.78 & 1.14 & 0.42 & 9.05 & 0.034 \\
\hline & 6 & 14.15 & 7.81 & 4.39 & 1.48 & 0.52 & 10.46 & 0.011 \\
\hline & 7 & 8.75 & 4.25 & 3.50 & 0.82 & 0.25 & 9.37 & 0.013 \\
\hline & 8 & 4.80 & 2.90 & 1.18 & 0.49 & 0.12 & 10.21 & 0.286 \\
\hline
\end{tabular}

Fayoum J. Agric. Res. \& Dev., Vol. 20, No. 2, July, 2006 
2. The extracted $\mathrm{K}$ amounts by $0.01 \mathrm{~N} \mathrm{CaCl}_{2}$ solution:

The total $\mathrm{K}$ amounts $\left(\mathrm{m} \mathrm{mol}_{\mathrm{c}} / 100 \mathrm{~g}\right.$ soil) removed by repeated extraction with $0.01 \mathrm{~N} \mathrm{CaCl}_{2}$ (me/100 g soil) were calculated and presented in Table (4). The obtained data indicate that some of the investigated soil samples, i.e., Nos. 3, 4, 1 and 6 exhibited relatively higher amounts of Kreleased. These values confirmed the positive effect for the relatively fine texture on soil content of $\mathrm{K}$ and hence value of $\mathrm{K}$-released, due to their higher active surface areas of the inorganic colloids, which in turn is reflected positively on K-supplying power capacity of soil.

Table (4): Extracted $K$ amounts ( $m$ mol $/ 100 \mathrm{~g}$ soil) from the studied soil samples by repeated extraction with $0.01 \mathrm{~N} \mathrm{CaCl}_{2}$.

\begin{tabular}{|c|c|c|c|c|c|c|c|c|}
\hline \multirow{2}{*}{$\begin{array}{c}\text { Extraction } \\
\text { No. }\end{array}$} & \multicolumn{9}{|c|}{ Koil sample Nos. } \\
\cline { 2 - 9 } & \multicolumn{9}{|c|}{ Kom Ombo } & \multicolumn{4}{c|}{ Halaib \& Sahalateen } \\
\cline { 2 - 9 } & 1 & 2 & 3 & 4 & 5 & 6 & 7 & 8 \\
\hline 1 & 0.26 & 0.21 & 0.39 & 0.36 & 0.20 & 0.25 & 0.16 & 0.13 \\
\hline 2 & 0.11 & 0.11 & 0.18 & 0.13 & 0.10 & 0.11 & 0.09 & 0.04 \\
\hline 3 & 0.09 & 0.09 & 0.11 & 0.09 & 0.09 & 0.09 & 0.05 & 0.03 \\
\hline 4 & 0.07 & 0.07 & 0.09 & 0.07 & 0.07 & 0.07 & 0.03 & 0.02 \\
\hline 5 & 0.06 & 0.06 & 0.08 & 0.06 & 0.06 & 0.06 & 0.03 & 0.02 \\
\hline 6 & 0.05 & 0.04 & 0.07 & 0.05 & 0.05 & 0.04 & 0.03 & 0.02 \\
\hline 7 & 0.05 & 0.04 & 0.06 & 0.04 & 0.04 & 0.03 & -- & -- \\
\hline 8 & 0.05 & 0.04 & 0.05 & 0.03 & 0.04 & 0.03 & -- & -- \\
\hline 9 & -- & -- & 0.05 & 0.03 & 0.04 & 0.03 & -- & -- \\
\hline 10 & -- & -- & 0.05 & 0.03 & -- & -- & -- & -- \\
\hline
\end{tabular}

\section{Free energy of extracted $K$ amounts:}

Free energy values of $\Delta \mathrm{F}$ in calories/ $(\mathrm{mol})^{1 / 2}$ were calculated and presented in Table (5). Woodruff (1955 a \& b) suggested that the $\Delta \mathrm{F}$ values of -3500 calories/ (mol) $)^{1 / 2}$ or less are associated with K deficiency for plants. According to the aforementioned criterion, the obtained results in Table (5) indicate that the studied soil samples lie on the critical limit at the first extraction, except for soil samples Nos. 5, 6 and 8 , whose $\Delta \mathrm{F}$ values were $\leq-3500$ calories $/(\mathrm{mol})^{1 / 2}$, i.e., they are associated with $\mathrm{K}$ deficiency for plant. All $\Delta \mathrm{F}$ values tended to decrease in the following extraction for all the studied soils.

Table (5): The free energy values $\left\{\Delta \mathrm{F}\right.$ in calories $\left./(\mathrm{mol})^{1 / 2}\right\}$ of the extracted $\mathrm{K}$ amounts from the studied soil samples by $0.01 \mathrm{~N} \mathrm{CaCl}_{2}$ solution.

\begin{tabular}{|c|c|c|c|c|c|c|c|c|}
\hline \multirow{2}{*}{$\begin{array}{c}\text { Extraction } \\
\text { No. }\end{array}$} & \multicolumn{7}{|c|}{ Kom Ombo } & \multicolumn{5}{c|}{ Halaib \& Sahalateen } \\
\cline { 2 - 8 } & 1 & 2 & 3 & 4 & 5 & 6 & 7 & 8 \\
\hline 1 & -3460 & -3490 & -3209 & -3266 & -3549 & -34.29 & -3613 & -3868 \\
\hline 2 & -3968 & -3968 & -3712 & -3895 & -4003 & -3953 & -4096 & -4239 \\
\hline 3 & -4073 & -4088 & -3953 & -4082 & -4066 & -4117 & -4448 & -4573 \\
\hline 4 & -4224 & -4240 & -4073 & -4648 & -4137 & -4309 & -4582 & -4748 \\
\hline 5 & -4358 & -4332 & -4144 & -4740 & -4309 & -4419 & -4755 & -4991 \\
\hline 6 & -4426 & -4575 & -4224 & -4849 & -4419 & -4553 & -4755 & -4991 \\
\hline 7 & -4426 & -4575 & -4317 & -4983 & -4553 & -4725 & -4755 & -4991 \\
\hline 8 & -4426 & -4575 & -44.26 & -5156 & -4553 & -4725 & -- & -- \\
\hline 9 & -- & -- & -4426 & -5156 & -4553 & -4725 & -- & -- \\
\hline 10 & -- & -- & -4426 & -5156 & -- & -- & -- & -- \\
\hline
\end{tabular}

Fayoum J. Agric. Res. \& Dev., Vol. 20, No. 2, July, 2006 
POTASSIUM STATUS AND ITS EXTRACTION FREE ENERGY ... 215

So, it can be concluded that the amounts of K-released from the soils under consideration are insufficient for covering the K-requirements for the grown plants, and in turn these soils are in need for $\mathrm{K}$ fertilization, particularly upon the prevailing extensive cropping patterns.

\section{REFERENCES:}

Abdel Mawly, S.E. and El Sharkawy, A.A. (2004): Effect of soil moisture and integration of mineral and biofertilization of nitrogen on wheat growth. Assiut. J. of Agric. Sci., 35 (2): 237-261.

Cooper, M.; Gregory, D. and Harsis, H.C. (1987): Improving water use efficiency of annual crops in the rainfed farming system of West Asia and North Africa. Expt. Agric., 23: 113.

Hagin, J. and Feigenbaum, S. (1962): Estimation of available potassium reserves in soils. Potassium Symp., pp. 219-227.

Jackson, M.L. (1973): Soil Chemical Analysis. Prentice Hall of India Private Limited, New Delhi. Indian.

Mohamedine, A.A.; Mansour, S.F. and Abd EI Warth, M. (2003): Impact of irrigation frequencies and potassium levels on water consumptive use, water use efficiency and wheat yield at El Fayoum governorate. Egypt, J. Appl. Sci., 18 (11 B): 756-765.

Kilmer, V.J. and Alexander L.T. (1949): Methods of making mechanical analysis of soils. Soil Sci., 68: 15-24.

Richards, L.A. (1954): Diagnosis and Improvement of Saline and Alkali Soils. USDA Agric. Handbook No. 60, Washington, USA.

Woodruff, C.M. (1955 a): Ionic equilibrium between clay and dilute salt solution. Soil Sci. Soc. Amer. Proc., 19: 36-41.

Woodruff, C.M. (1955 b): Cation activities in the soil solution and energies of cation exchange. Soil Sci. Soc. Amer. Proc., 19: 98-99.

$$
\begin{aligned}
& \text { حالة البوتاسيوم وطاقة إستخلاصه الحرة فى بعض الأراضى المستصلحة حديثا فى مصر العليا }
\end{aligned}
$$

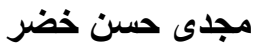

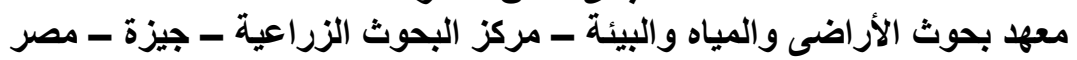

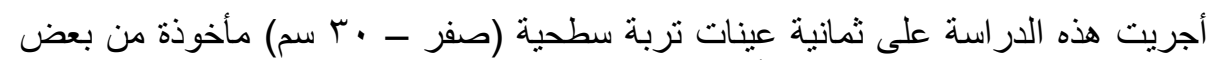

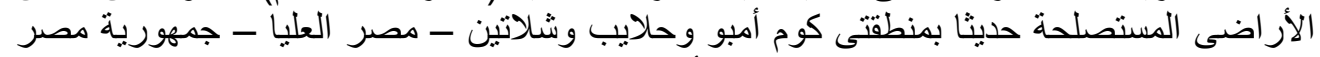

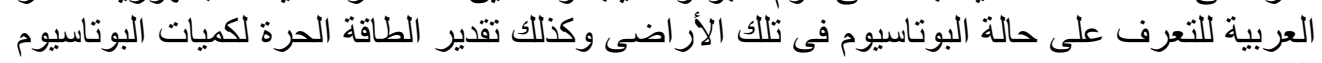

$$
\begin{aligned}
& \text { المستخلصة من التربة. }
\end{aligned}
$$

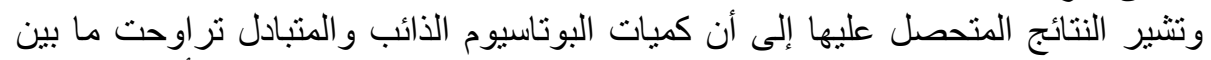

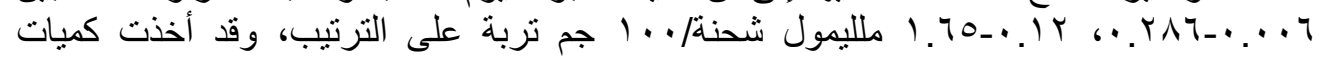

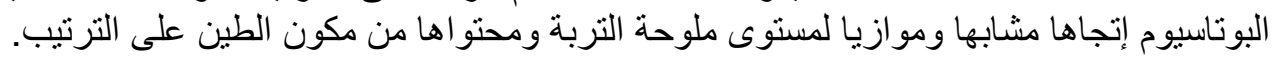

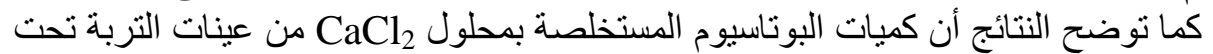

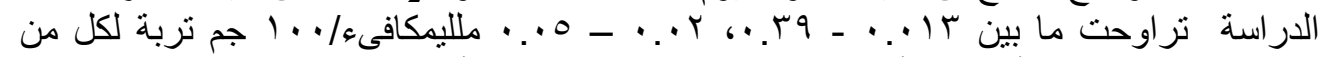

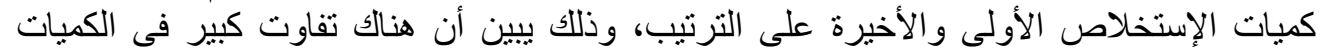

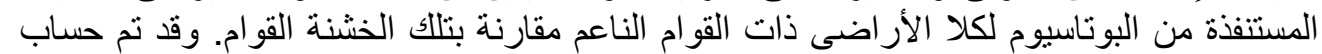

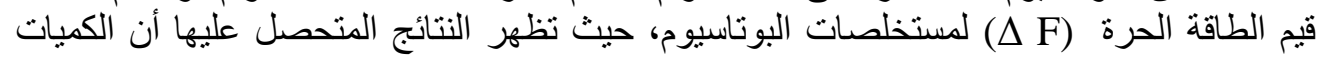

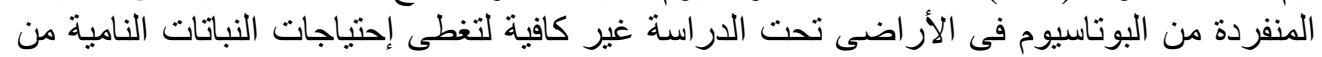

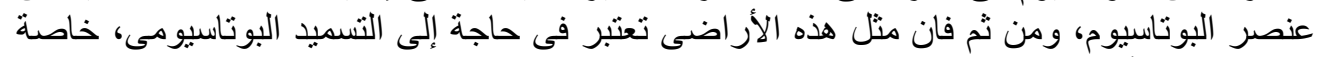

$$
\begin{aligned}
& \text { تحت ظروف أنظمة التكثيف المحصولى النيائد. }
\end{aligned}
$$

Fayoum J. Agric. Res. \& Dev., Vol. 20, No. 2, July, 2006 